\title{
Anne-Sophie Kutyla, Tristan Corbière. Une curiosité esthétique
}

\section{Maria Emanuela Raffi}

\section{(2) OpenEdition}

\section{Journals}

\section{Edizione digitale}

URL: http://journals.openedition.org/studifrancesi/5716

DOI: $10.4000 /$ studifrancesi.5716

ISSN: 2421-5856

\section{Editore}

Rosenberg \& Sellier

\section{Edizione cartacea}

Data di pubblicazione: 1 septembre 2011

Paginazione: 444

ISSN: 0039-2944

\section{Notizia bibliografica digitale}

Maria Emanuela Raffi, «Anne-Sophie Kutyla, Tristan Corbière. Une curiosité esthétique», Studi Francesi [Online], 164 (LV | II) | 2011, online dal 30 novembre 2015, consultato il 13 janvier 2021. URL: http:// journals.openedition.org/studifrancesi/5716 ; DOI: https://doi.org/10.4000/studifrancesi.5716

Questo documento è stato generato automaticamente il 13 janvier 2021.

\section{(ब) $\odot \Theta$}

Studi Francesi è distribuita con Licenza Creative Commons Attribuzione - Non commerciale - Non opere derivate 4.0 Internazionale. 


\title{
Anne-Sophie Kutyla, Tristan Corbière. Une curiosité esthétique
}

\author{
Maria Emanuela Raffi
}

NOTIZIA

ANNE-SOPHIE KUTYLA, Tristan Corbière. Une curiosité esthétique, Paris, Eurédit, 2010, 122 pp.

Si segnala la «nouvelle édition revue et corrigée» di questo piacevole saggio sulla presenza dell'immagine, e particolarmente dell'immagine caricaturale, nell'opera di Tristan Corbière, pubblicato in prima edizione nel 2000. 